\title{
DEFORMATION AND ENERGY ABSORPTION OF FIBER METAL LAMINATES (FMLS) AFTER BALLISTIC IMPACT LOAD
}

\author{
Muhammad Syaiful Fadly ${ }^{1)}$, Anindito Purnowidodo ${ }^{2)}$, Putu Hadi Setyarini $^{3)}$ \\ Program Studi Teknik Mesin, Fakultas Teknik, Universitas Brawijaya \\ Jl. Mayjend Haryono 167, Kota Malang, Jawa Timur \\ Email : ${ }^{1}$ muhsyaifulfadly@gmail.com
}

\begin{abstract}
Estimated damage levels from ballistic impact zones provide valuable information to make bulletproof materials more effective. This study aims to determine the impact of ballistics including deformation and energy absorption in fiber metal laminates (FMLs) that collide with $9 \mathrm{~mm}$ FMJ caliber bullets at speeds of $426 \mathrm{~m} / \mathrm{s}$. Finite element method modeling is done using ANSYS 18.1 workbench software. The simulation results show that FMLs can hold the bullet rate with deformation on the back of the target $\left(D O P_{I I I}\right)$ of 8,55 mm and total energy absorption of 426,59 J at 0,000095 s. The combination of two materials, Al 5083 in the outer layer and kevlar/epoxy as the core, results in faster energy absorption and maximum stress concentrations only occur in the kevlarlepoxy so there is no damage to the first and subsequent layers.
\end{abstract}

Keywords : Ballistic, 9 mm FMJ, fiber metal laminates (FMLs), Johnson-Cook plasticity, Orthotropic.

\section{Pendahuluan}

Investigasi perilaku dari bahan akibat beban balistik sangat penting ketika merancang material armor atau material tahan peluru yang lebih baik. Pengembangan bahan dan material tahan peluru adalah suatu bisnis yang sangat mahal, pengembangan material tahan peluru dengan simulasi numerik perlu dilakukan untuk mengurangi biaya dari proses eksperimen. Simulasi numerik juga digunakan untuk memahami fenomena penetrasi peluru pada target yang sulit atau bahkan tidak mungkin diperoleh dari hasil pengujian secara eksperimen.

Bahan yang biasanya digunakan dalam pembuatan rompi anti peluru adalah kain sintetis yang terbuat dari serat berkekuatan tinggi seperti kevlar (aramid), spectra, twaron dan dyneema [1]. Perkembangan teknologi senjata selama beberapa tahun terakhir terus meningkat dan semakin lebih canggih. Perkembangan tersebut menyebabkan performa dari perlengkapan perlindungan yang dibutuhkan juga menjadi lebih tinggi [2]. Serangkaian percobaan untuk mengetahui kinerja balistik plat logam monolitik dan berlapis-lapis akibat dampak oleh proyektil tumpul telah dilakukan Wei dkk [3]. Plat berlapis disusun dalam berbagai kombinasi yang ditembakkan dengan pistol gas. Hasil penelitian menunjukkan target berlapis dengan celah udara lebih besar memiliki ketahanan balistik lebih baik dibandingkan dengan celah udara kecil.

Serat kevlar (aramid) yang memiliki sifat kekuatan yang tinggi, peredam yang yang baik (vibration damping) ketika mengenai benturan dari peluru, maka energi kinetik dari peluru akan diredam dan didistribusikan ke penampang kevlar yang luas melalui sejumlah besar deformasi. Deformasi penekanan kearah dalam (shock wave) searah dengan penentasi dari peluru ini akan menimbulkan regangan yang besar sampai batas tertentu sebelum mengalami kegagalan [4]. 


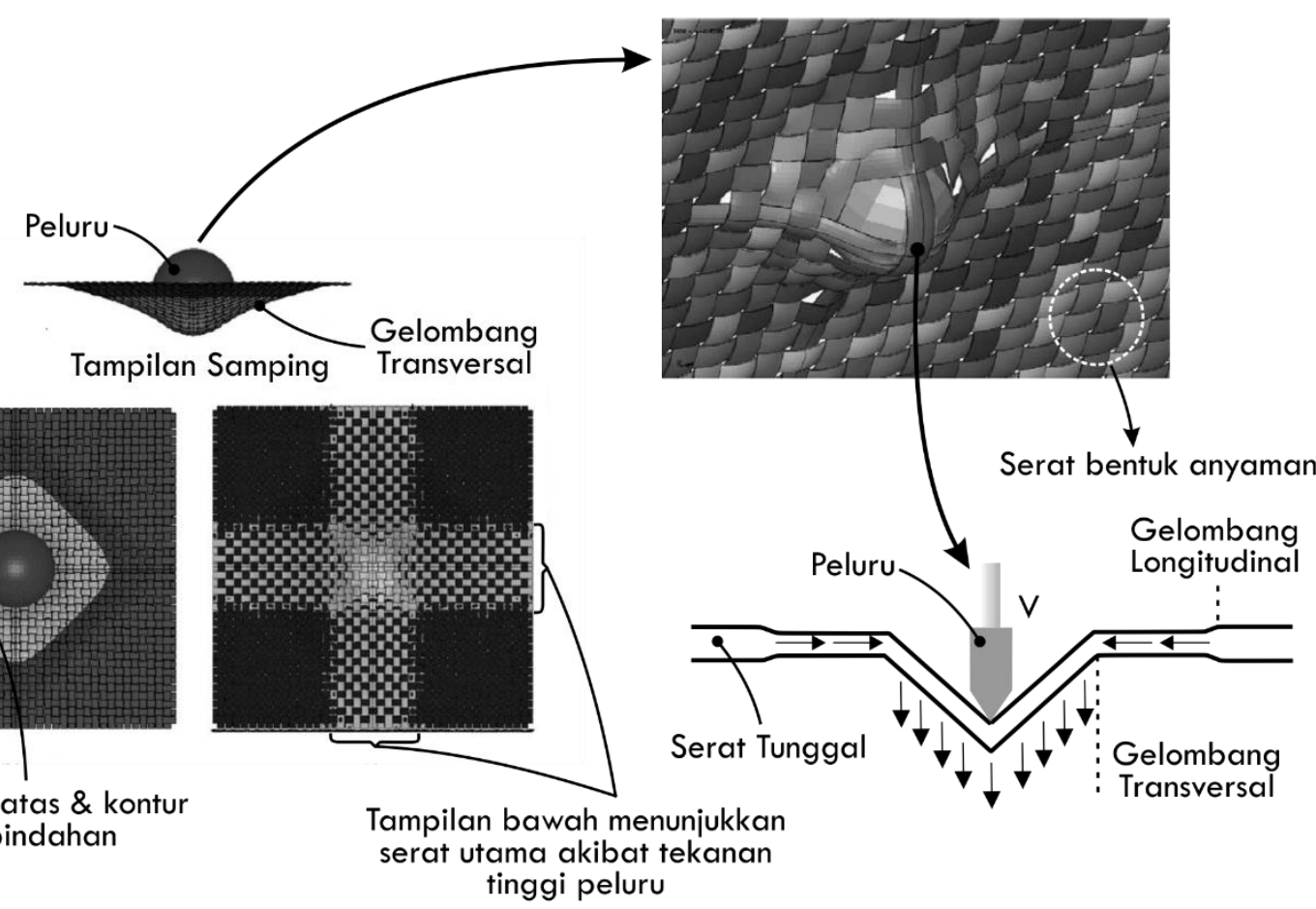

Gambar 1. Dampak peluru pada lapisan serat [4]

Dampak kecepatan balistik yang tinggi menyebabkan bahan target berperilaku seperti cairan dan menghasilkan perambatan gelombang dalam struktur seperti ditunjukkan pada Gambar 1. Respon dampak dari satu lapis kain dan serat tunggal menunjukkan kesamaan menghasilkan gelombang transversal dan longitudinal saat bersentuhan langsung dengan peluru. Momentum peluru ditransfer pada serat utama menyebabkan regangan dan mengalami kegagalan akibat tekanan yang melebihi batas regangan maksimum.

Perlindungan balistik terhadap peluru berkecepatan tinggi, lebih efektif dengan menggunakan bahan berlapis (laminasi) dibandingkan dengan bahan tunggal [5]. Perpaduan antara plat aluminium yang memiliki kekuatan dan ketahanan impak yang tinggi serta kepadatan (density) yang rendah dengan komposit kevlar/epoxy memiliki struktur yang kuat, sifat peredam yang baik (vibration damping), dan ketahanan tinggi terhadap beban dinamis dalam bentuk laminasi (fiber metal laminates) dapat dilakukan sebagai alternatif pembuatan material tahan peluru.

\section{Metodologi Penelitian}

Dalam penelitian ini, perilaku balistik dari fiber metal laminates (FMLs) diperoleh dari simulasi numerik menggunakan model elemen hingga (explicit dynamics) dari software ANSYS 18.1 Workbench. FMLs yang digunakan dengan konfigurasi 3 lapisan (Triple layered) terdiri dari dua lembar plat aluminium 5083 pada permukaan luar dan kevlar/epoxy sebanyak 4 layer sebagai inti (core). Pengujian balistik berdasarkan standard NIJ 0101.06 type III-A dari U.S Department of Justice [6], menggunakan peluru kaliber $9 \mathrm{~mm}$ FMJ (full metal jacket) dengan kecepatan $426 \mathrm{~m} / \mathrm{s}$. Model material dari peluru dan plat aluminium 5083 menggunakan model plastisitas Johnson-Cook pada persamaan (1) [7-10] sedangkan untuk kevlar/epoxy menggunakan model material orthotropik pada persamaan (4) [11]. Data material untuk kevlar/epoxy pada simulasi ditunjukkan pada Tabel 1.

$$
\sigma_{e q}=\left[A+B \varepsilon^{n}\right]\left[1+C \ln \dot{\varepsilon}^{*}\right]\left[1-\left(T^{*}\right)^{m}\right]
$$


dengan $\sigma_{e q}$ adalah tegangan ekuivalen (MPa), $A$ adalah tegangan luluh (MPa), $B$ adalah konstanta pengerasan $(\mathrm{MPa}), \varepsilon$ adalah regangan ekuivalen, $n$ adalah eksponen pengerasan, $C$ adalah kontanta laju regangan dan $m$ adalah parameter temperatur softening. Temperatur ditentukan dari persamaan (2) :

$$
T^{*}=\frac{\left(T-T_{r}\right)}{\left(T_{m}-T_{r}\right)}
$$

di mana $T$ adalah temperatur uji, $T_{r}$ adalah temperatur ruang dan $T_{m}$ adalah temperatur leleh material. Tingkat regangan diberikan pada persamaan (3) :

$$
\dot{\varepsilon}^{*}=\frac{\dot{\varepsilon}}{\varepsilon_{o}}
$$

dengan $\dot{\varepsilon}$ adalah laju regangan uji dan $\varepsilon_{o}$ adalah laju regangan referensi. Geometri dan bentuk meshing dari peluru dan target seperti pada Gambar 2 sedangkan data material untuk peluru dan plat Al 5083 seperti ditunjukkan pada Tabel 2.

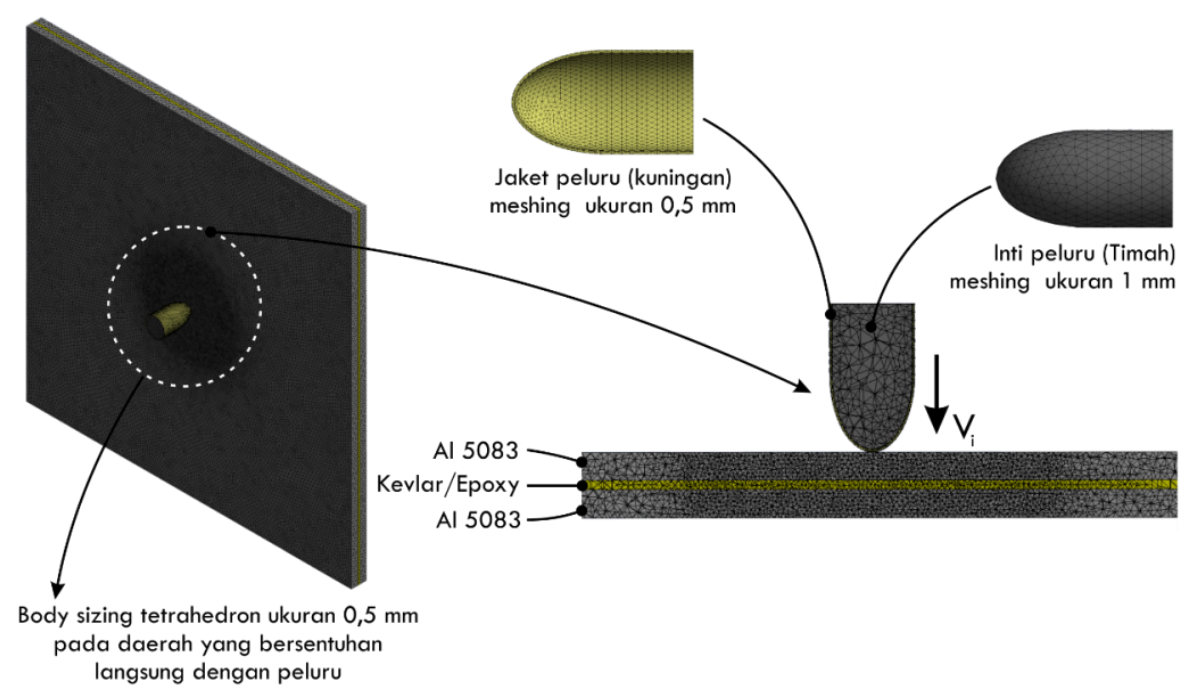

Gambar 2. Geometri dan bentuk meshing pada simulasi

Tabel 1. Data material kevlar/epoxy [12]

\begin{tabular}{|c|c|c|c|}
\hline Parameter & Simbol & Satuan & Kevlar/epoxy \\
\hline Density & $\rho$ & $\mathrm{kg} / \mathrm{m}^{3}$ & 1440 \\
\hline Young modulus x & $\mathrm{E}_{1}$ & $\mathrm{~Pa}$ & $1,85 \times 10^{10}$ \\
\hline Young modulus y & $\mathrm{E}_{2}$ & $\mathrm{~Pa}$ & $1,85 \times 10^{10}$ \\
\hline Young modulus z & $\mathrm{E}_{3}$ & $\mathrm{~Pa}$ & $6 \times 10^{9}$ \\
\hline Poisson's ratio xy & $v_{12}$ & - & 0,25 \\
\hline Poisson's ratio yz & $v_{13}$ & - & 0,33 \\
\hline Poisson's ratio xz & $v_{23}$ & - & 0,33 \\
\hline Shear modulus xy & $\mathrm{G}_{12}$ & $\mathrm{~Pa}$ & $7,7 \times 10^{8}$ \\
\hline Shear modulus yz & $\mathrm{G}_{13}$ & $\mathrm{~Pa}$ & $5,43 \times 10^{9}$ \\
\hline Shear modulus xz & $\mathrm{G}_{23}$ & $\mathrm{~Pa}$ & $5,43 \times 10^{9}$ \\
\hline
\end{tabular}


Muhammad Syaiful Fadly, Anindito Purnowidodo, Putu Hadi Setyarini

Tabel 2. Data material peluru dan plat aluminium 5083 [7-10]

\begin{tabular}{|c|c|c|c|c|c|}
\hline \multirow{2}{*}{ Parameter } & \multirow{2}{*}{ Simbol } & \multirow{2}{*}{ Satuan } & \multicolumn{2}{|c|}{ Peluru } & Aluminium \\
\cline { 4 - 6 } & & & Timah & Kuningan & $\mathbf{5 0 8 3}$ \\
\hline Density & $\rho$ & $\mathrm{kg} / \mathrm{m}^{3}$ & 10660 & 8520 & 2660 \\
\hline Elastic modulus & $\mathrm{E}$ & $\mathrm{MPa}$ & 1000 & 115000 & 70000 \\
\hline Poisson's ratio & $v$ & - & 0,42 & 0,31 & 0,33 \\
\hline Specific heat & $\mathrm{C}_{\mathrm{p}}$ & $\mathrm{J} / \mathrm{kg}-\mathrm{K}$ & 124 & 385 & 900 \\
\hline \multicolumn{2}{|c|}{ Parameter model plastisitas Johnson-Cook } & \\
\hline Yield stress constant & $\mathrm{A}$ & $\mathrm{MPa}$ & 24 & 206 & 210 \\
\hline Hardening constant & $\mathrm{B}$ & $\mathrm{MPa}$ & 300 & 505 & 620 \\
\hline Hardening exponent & $\mathrm{n}$ & - & 1 & 0,42 & 0,375 \\
\hline Strain rate constant & $\mathrm{C}$ & - & 0,1 & 0,01 & 0,0125 \\
\hline Thermal softening exponent & $\mathrm{m}$ & - & 1 & 1,68 & 1,525 \\
\hline Melting temperature & $\mathrm{T}_{\mathrm{m}}$ & $\mathrm{K}$ & 760 & 1189 & 843,15 \\
\hline Room temperature & $\mathrm{T}_{\mathrm{r}}$ & $\mathrm{K}$ & 293 & 293 & 293 \\
\hline reference strain rate & $\varepsilon_{\mathrm{o}}$ & $\mathrm{s}^{-1}$ & $5 \times 10^{-4}$ & $5 \times 10^{-4}$ & 1 \\
\hline
\end{tabular}

analisa untuk memprediksi perilaku bahan komposit yang diperkuat serat dalam penelitian ini yaitu kevlar/epoxy untuk tiga dimensi, maka matriks kekakuannya yaitu :

$$
\left[\begin{array}{l}
\sigma_{1} \\
\sigma_{2} \\
\sigma_{3} \\
\tau_{23} \\
\tau_{31} \\
\tau_{12}
\end{array}\right]=\left[\begin{array}{cccccc}
C_{11} & C_{12} & C_{13} & 0 & 0 & 0 \\
C_{21} & C_{22} & C_{23} & 0 & 0 & 0 \\
C_{31} & C_{32} & C_{33} & 0 & 0 & 0 \\
0 & 0 & 0 & C_{44} & 0 & 0 \\
0 & 0 & 0 & 0 & C_{55} & 0 \\
0 & 0 & 0 & 0 & 0 & C_{66}
\end{array}\right]\left[\begin{array}{c}
\varepsilon_{1} \\
\varepsilon_{2} \\
\varepsilon_{3} \\
\gamma_{23} \\
\gamma_{31} \\
\gamma_{12}
\end{array}\right]
$$

hubungan regangan tegangannya yaitu dengan invers matriks $\left[\mathrm{C}_{\mathrm{ij}}\right]$ sehingga menjadi $\left[\mathrm{S}_{\mathrm{ij}}\right]$. Untuk bahan orthotropik, konstanta dari komponen matriks kekakuan adalah [13] :

$$
\left[\mathrm{S}_{\mathrm{ij}}\right]=\left[\begin{array}{cccccc}
\frac{1}{\mathrm{E}_{1}} & -\frac{v_{21}}{\mathrm{E}_{2}} & -\frac{v_{31}}{\mathrm{E}_{3}} & 0 & 0 & 0 \\
-\frac{v_{12}}{\mathrm{E}_{1}} & \frac{1}{\mathrm{E}_{2}} & -\frac{v_{32}}{\mathrm{E}_{3}} & 0 & 0 & 0 \\
-\frac{v_{13}}{\mathrm{E}_{1}} & -\frac{v_{23}}{\mathrm{E}_{2}} & \frac{1}{\mathrm{E}_{3}} & 0 & 0 & 0 \\
0 & 0 & 0 & \frac{1}{\mathrm{G}_{23}} & 0 & 0 \\
0 & 0 & 0 & 0 & \frac{1}{\mathrm{G}_{31}} & 0 \\
0 & 0 & 0 & 0 & 0 & \frac{1}{\mathrm{G}_{12}}
\end{array}\right]
$$


Variabel dan konfigurasi target dalam penelitian ini seperti ditunjukkan pada Tabel 3. Deformasi dan total energi yang diserap target diperoleh dari simulasi dengan mengatur data solusi yang dibutuhkan.

Tabel 3. Konfigurasi Sampel

\begin{tabular}{|c|c|c|}
\hline Konfigurasi & Geometri & Keterangan \\
\hline Al 5083 & $\mathbf{D}$ & Plat Al 5083 ketebalan $3 \mathrm{~mm}$ \\
\hline Kevlar/Epoxy & $\mathbf{D}$ & Kevlar/epoxy dengan 4 layer \\
\hline Fiber Metal Laminates (FMLs) & $D$ & $\begin{array}{l}\text { Plat Al } 5083 \text { tebal } 3 \mathrm{~mm} \text { - kevlar/epoxy } \\
4 \text { layer - plat Al } 5083 \text { tebal } 3 \mathrm{~mm}\end{array}$ \\
\hline
\end{tabular}

\section{Hasil dan Pembahasan}

Hasil simulasi numerik diperoleh deformasi dan total energi yang diserap target pada saat peluru menembus dan berhenti pada target. Ketahanan balistik target material terhadap beban impak balistik dipengaruhi oleh deformasi yang meliputi kedalaman penetrasi dari peluru pada target. Ketahanan balistik semakin meningkat dengan semakin berkurangnya kedalaman penetrasi peluru. Pengukuran deformasi FMLs meliputi kedalaman penetrasi plat bagian depan $\left(\mathrm{DOP}_{\mathrm{I}}\right)$, kedalaman penetrasi kevlar/epoxy $\left(\mathrm{DOP}_{\mathrm{II}}\right)$ dan tonjolan belakang (DOP $\mathrm{III})$. Hasil deformasi terhadap waktu ditunjukkan pada Gambar 3.
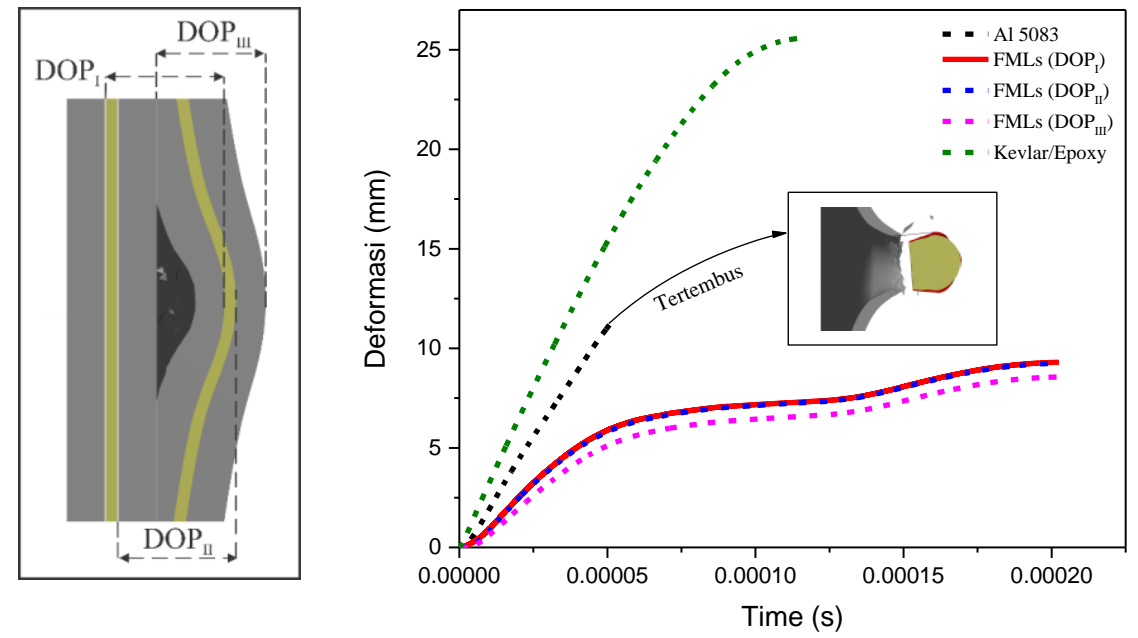

Gambar 3. Nomenklatur \& Grafik deformasi vs waktu 
Gambar 3 menununjukkan semakin meningkatnya waktu maka deformasi yang terbentuk semakin besar. Deformasi bagian belakang dari konfigurasi plat Al 5083 yaitu sebesar 11,25 mm pada waktu 0,000051 s kemudian plat tertembus oleh peluru. Hasil yang berbeda ditunjukkan pada kevlar/epoxy dan FMLs yang tidak tertembus oleh peluru dengan deformasi akhir bagian belakang untuk kevlar/epoxy sebesar $25,59 \mathrm{~mm}$ pada waktu 0,00017 s. Sedangkan kedalaman penetrasi bagian depan (DOP $)$ FMLs sebesar 9,29 mm, kedalaman penetrasi kevlar/epoxy ( $\mathrm{DOP}_{\mathrm{II}}$ ) sebesar $9,25 \mathrm{~mm}$ dan tinggi tonjolan belakang ( $\left.\mathrm{DOP}_{\mathrm{III}}\right)$ sebesar 8,55 mm pada waktu 0,0002 s. Kevlar/epoxy mengalami deformasi yang besar saat menahan laju dari peluru dibandingkan FMLs. Akibat dampak balistik menyebabkan target mengalami deformasi sehingga kecepatan peluru semakin berkurang. Kecepatan peluru selama penetrasi pada setiap konfigurasi target ditunjukkan pada Gambar 4.

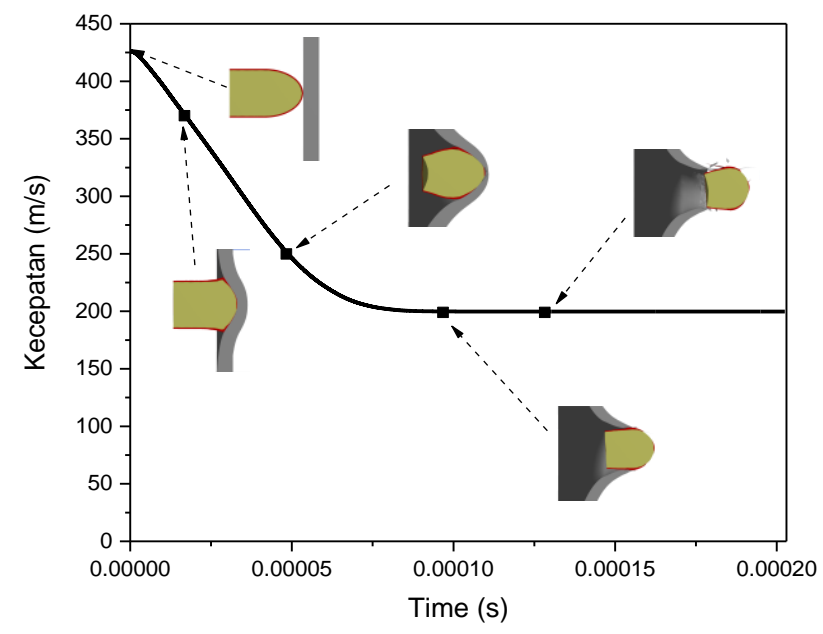

(a)



(b)



(c)

Gambar 4. Kecepatan peluru selama penetrasi pada target ;

(a) Al 5083, (b) Kevlar/Epoxy, (c) FMLs

Gambar 4 menunjukkan bahwa kevlar/epoxy dan FMLs yang tidak tertembus peluru menghasilkan kecepatan sisa yang berkurang ke nol seiring dengan berjalannya waktu penetrasi dari peluru. Kecepatan peluru mencapai nilai negatif karena arah dari peluru berbalik atau memantul setelah penetrasi pada terget. Pada konfigurasi Al 5083 tertembus oleh peluru sehingga menghasilkan kecepatan sisa yaitu sebesar 199,73 m/s. Kevlar/epoxy 
memiliki daya redam yang baik sehingga walaupun mengalami deformasi yang besar, beban balistik dari peluru pada kevlar/epoxy ditransfer ke seluruh penampang target sehingga mampu menahan laju peluru, akibatnya peluru akan mengalami penurunan kecepatan yang maksimum meskipun lambat yaitu pada waktu 0,00012 s dibandingkan FMLs yaitu pada waktu $0,000095 \mathrm{~s}$. Energi yang diserap untuk setiap konfigurasi seperti yang ditunjukkan pada Gambar 5.

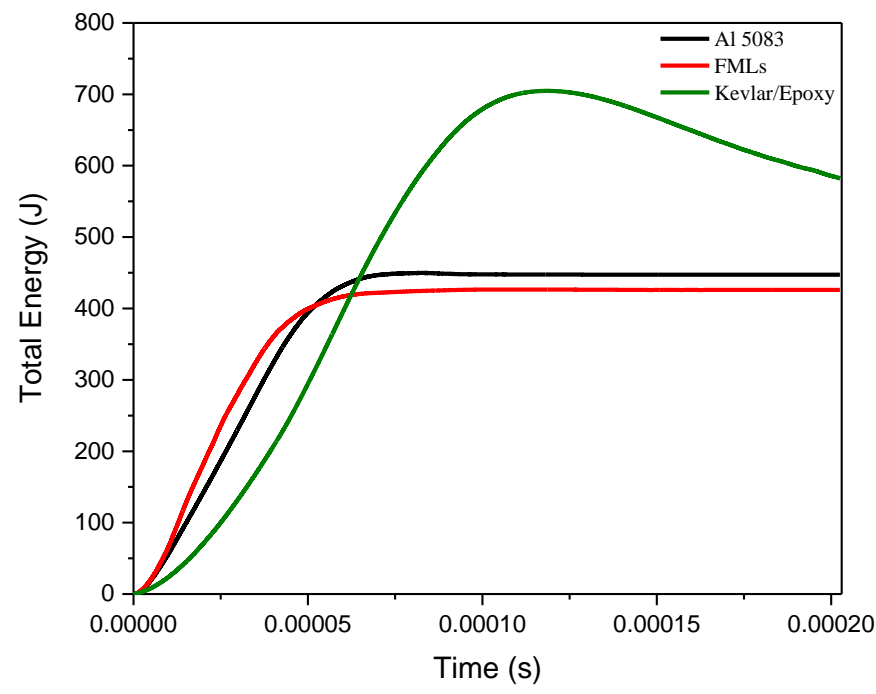

Gambar 5. Total energi yang diserap target

Energi yang diserap target mengalami peningkatan ketika penetrasi peluru pada target kemudian mengalami penurunan dan selanjutnya cenderung konstan seiring dengan berjalannya waktu. Penyerapan energi dari kevlar/epoxy cenderung lambat dibandingkan dengan Al 5083 dan FMLs. Total Energi yang diserap kevlar/epoxy meningkat mencapai titik maksimum yaitu sebesar 704,84 J pada waktu 0,00018 s. Sedangkan untuk konfigurasi Al 5083 energi maksimum yaitu sebesar 449,84 J pada waktu 0,000082 s kemudian energi tidak berubah atau konstan seiring dengan berjalannya waktu. Penyerapan energi pada FMLs meningkat secara signifikan lebih cepat dibandingkan Al 5083 dan kevlar/epoxy yaitu dengan energi maksimum sebesar 426,59 J pada waktu 0,000095 s. Penyerapan energi maksimum pada setiap konfigurasi target ditunjukkan pada Gambar 6 .

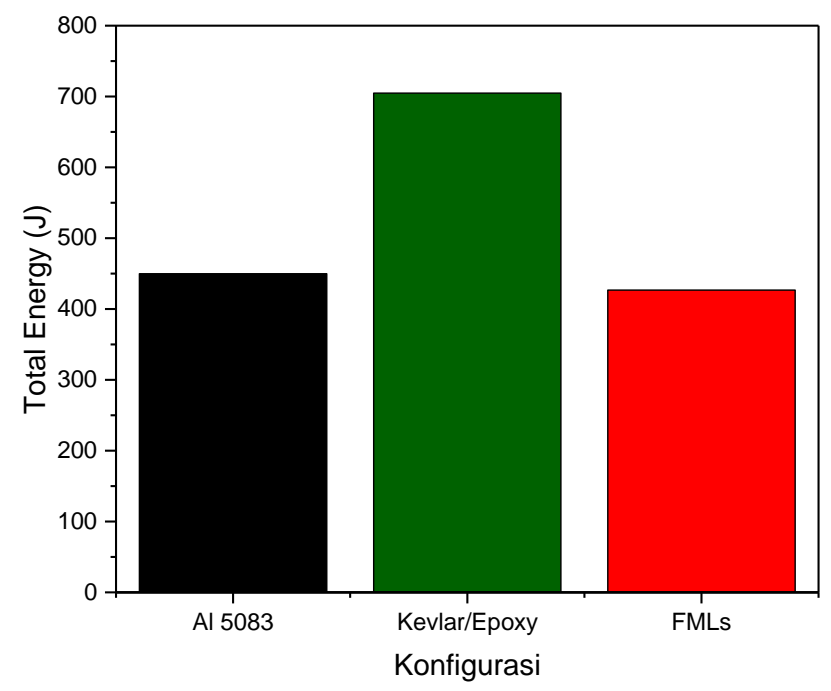

Gambar 6. Total energi yang diserap target pada saat maksimum 
Gambar 6 menunjukkan penyerapan energi maksimum dari kevlar/epoxy lebih tinggi dibandingkan Al 5083 dan FMLs, akan tetapi meskipun penyerapan energinya besar, kevlar/epoxy menghasilkan deformasi yang besar pada saat penetrasi oleh peluru. Penggunaan plat aluminium pada lapisan depan dari FMLs menghasilkan penyerapan energi yang dominan sehingga dapat menghentikan laju dari peluru dan deformasi yang terbentuk lebih kecil. Tegangan ekuivalen setiap konfigurasi target pada saat penyerapan energi maksimum dan berhenti atau tertembus oleh peluru seperti ditunjukkan pada Gambar 7 .

a

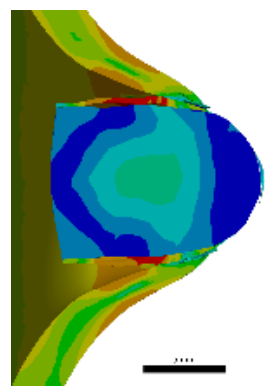

Al 5083

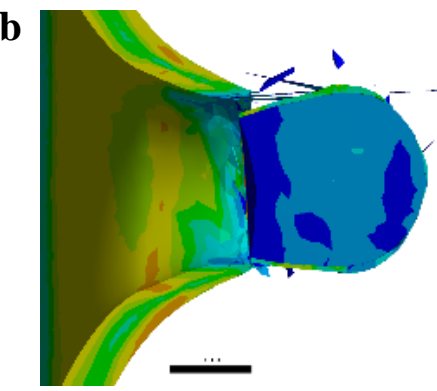

a
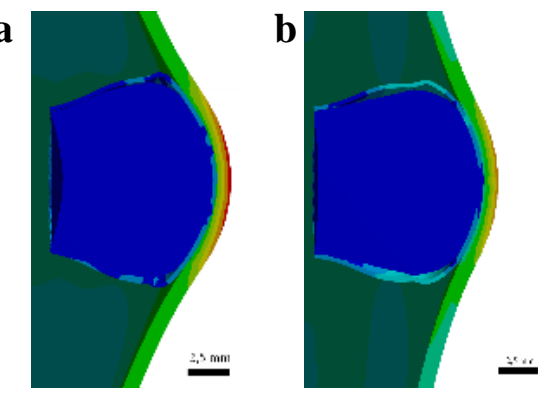

Kevlar/Epoxy

$\mathrm{t}=\mathbf{0 , 0 0 0 1 1} \mathrm{s} \quad \mathrm{t}=\mathbf{0 , 0 0 0 1 6} \mathrm{s}$

$$
\mathrm{t}=\mathbf{0 , 0 0 0 0 8 2 \mathrm { s }} \quad \mathrm{t}=\mathbf{0 , 0 0 0 1 2} \mathrm{s}
$$
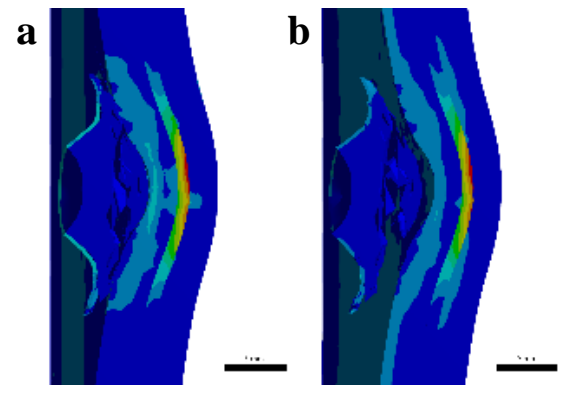

FMLs

$$
\mathrm{t}=\mathbf{0 , 0 0 0 1 0 \mathrm { s }} \mathrm{t}=\mathbf{0 , 0 0 0 1 6 \mathrm { s }}
$$

Gambar 7. Tegangan ekuivalen target ; (a) Penyerapan energi maksimum, (b) Penyerapan energi konstan

Gambar 7 menunjukkan beban impak balistik dari peluru tidak mampu ditahan oleh target pada konfigurasi Al 5083 sehingga mencapai tegangan maksimum dan target terlubangi yaitu pada waktu setelah $0,000082 \mathrm{~s}$. Berbeda dengan konfigurasi kevlar/epoxy yang mampu menyerap energi lebih besar sehingga menghasilkan tegangan maksimum pada daerah disekitar dari dampak peluru, kemudian energi turun yang ditunjukkan semakin berkurangnya tegangan maksimum pada terget. Sedangkan untuk konfigurasi FMLs menunjukkan penyerapan energi maksimum terjadi yaitu pada waktu $0,00010 \mathrm{~s}$ ditandai dengan tegangan maksimum yang terjadi pada lapisan kedua yaitu kevlar/epoxy, kemudian energi cenderung konstan pada waktu 0,00016 s.

\section{Kesimpulan}

Fiber metal laminates (FMLs) dapat menahan laju dari peluru yaitu dengan mentransfer tegangan maksimum pada lapisan kedua yaitu kevlar/epoxy untuk meredam benturan dari peluru sehingga tidak terjadi kerusakan balistik pada lapisan pertama dan selanjutnya. Penggunaan kevlar/epoxy sebagai peredam pada lapisan tengah dari FMLs menghasilkan deformasi yang semakin kecil dan penyerapan energi maksimum yang cenderung lebih cepat. 


\section{Ucapan Terimakasih}

Penulis mengucapkan terima kasih kepada pembimbing tesis yaitu Dr. Eng. Anindito Purnowidodo, ST., M.Eng selaku pembimbing I dan Dr. Putu Hadi Setyarini, ST., MT selaku pembimbing II atas saran dan masukan dalam pelaksanaan penelitian sampai penulisan karya tulis ini serta kepada semua pihak yang telah membantu penulis dalam penyelesaian karya tulis ini.

\section{Daftar Pustaka}

[1] de Oliveira Braga, F., Milanezi, T. L., Monteiro, S. N., Louro, L. H. L., Gomes, A. V., \& Lima Jr, É. P. (2018). Ballistic comparison between epoxy-ramie and epoxy-aramid composites in Multilayered Armor Systems. Journal of materials research and technology, 7(4), 541-549.

[2] Hazell, P. J. (2015). Armour: materials, theory, and design. CRC Press.

[3] Wei, Z., Yunfei, D., Sheng, C. Z., \& Gang, W. (2012). Experimental investigation on the ballistic performance of monolithic and layered metal plates subjected to impact by blunt rigid projectiles. International Journal of Impact Engineering, 49, 115-129.

[4] Cheeseman, B. A., \& Bogetti, T. A. (2003). Ballistic impact into fabric and compliant composite laminates. Composite structures, 61(1-2), 161-173.

[5] Monteiro, S. N., Lima, É. P., Louro, L. H. L., Da Silva, L. C., \& Drelich, J. W. (2015). Unlocking function of aramid fibers in multilayered ballistic armor. Metallurgical and materials transactions A, 46(1), 37-40.

[6] U.S Department of Justice. (2009). Ballistic Resistance Of Body Armor. New York: Nova Science.

[7] Crouch, I. (Ed.). (2016). The science of armour materials. Woodhead Publishing.

[8] Børvik, T., Dey, S., \& Clausen, A. H. (2009). Perforation resistance of five different high-strength steel plates subjected to small-arms projectiles. International Journal of Impact Engineering, 36(7), 948-964.

[9] Tse, K. M., Tan, L. B., Yang, B., Tan, V. B. C., \& Lee, H. P. (2017). Effect of helmet liner systems and impact directions on severity of head injuries sustained in ballistic impacts: a finite element (FE) study. Medical \& biological engineering \& computing, 55(4), 641-662.

[10] Rashed, A., Yazdani, M., Babaluo, A. A., \& Hajizadeh Parvin, P. (2016). Investigation on high-velocity impact performance of multi-layered alumina ceramic armors with polymeric interlayers. Journal of Composite Materials, 50(25), 3561-3576.

[11] Kaw, A. K. (2005). Mechanics of composite materials. CRC press.

[12] Soydan, A. M., Tunaboylu, B., Elsabagh, A. G., Sarı, A. K., \& Akdeniz, R. (2018). Simulation and experimental tests of ballistic impact on composite laminate armor. Advances in Materials Science and Engineering, 2018.

[13] Jones, R. M. (2014). Mechanics of composite materials. CRC press. 
Muhammad Syaiful Fadly, Anindito Purnowidodo, Putu Hadi Setyarini 